\title{
METODE PEMBELAJARAN BAHASA ARAB
}

\section{Zulfiah Sam}

\begin{abstract}
Abstract

The assembling of learning method will not work effectively and efficiently as a companion media in learning without a sufficient method knowledge. A method of traditional Arabic Learning is an arabic learning method that focused on "language as the scientific tradition" so that learning an arabic means learning an arabic in details, either grammatically/sintactically (Qawa'tid alNahwu), morpheme/accidence (Qawā'id al-Sarf) or literature (ādāb). The main aspects in learning arabic are : listening, speaking, reading and writing. The four aspects are mutual related, for example, a listening skill contributes to a development of speaking skill, both skills are strengthened by reading skill, while writing skill contributes to a reading skill in the text or document form.
\end{abstract}

Keyword : Metode, Bahasa Arab.

\section{PENDAHULUAN}

Metode pembelajaran Bahasa Arab telah mendapatkan perhatian dari para ahli pembelajaran Bahasa dengan melakukan berbagai kajian dan peneitian untuk mengetahui efektifitas dan kesuksekan berbagai metode pembelajaran. Yaitu bahwa metode menjadi hal yang sangat penting dalam studi Bahasa Asing termasuk didalamnya adalah belajar Bahasa Arab. Kesuksesan belajar ini sangat barkaitan dengan berbagai faktor yang mendukungnya yaitu faktor antara siswa dengan guru, karena hal ini adalah metode atau cara yang dipakai dalam pembelajaran untuk mempermudah seseorang mendapatkan ilmu pengetahuan kebahasaan, tetapi ada kalanya juga seseorang mendapatkan kesulitan jika dalam belajarnya tidak sesuai dengan karakteristik metodenya atau tidak tepat sasaran. Oleh karena itu metode yang tepat dalam belajar sebaiknya melihat konsep dari sebuah metode belajar Bahasa Arabnya.

Bahasa Arab sebagaimana kita ketahui merupakan bahasa yang termasuk dalam rumpun bahasa Semit yang maju, dimana bahasa arab juga sebagai bahasa 
al-Qur'ān. ${ }^{1}$ Selain itu kosa kata dalam bahasa Indonesia juga banyak yang menyerap dari bahasa Arab.

Bahasa Arab dapat didefinisikan sebagai berikut:

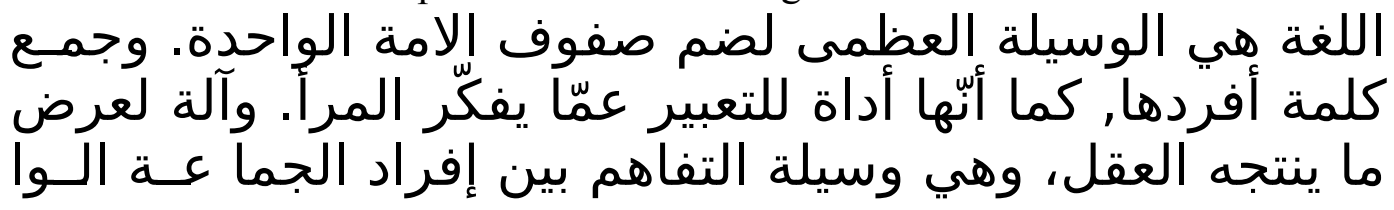

"Dari penjelasan diatas, dapat dijelaskan bahwa pembelajaran bahasa Arab adalah proses interaksi peserta didik dengan lingkungannya (dalam hal ini adalah bahasa Arab) sehingga terjadi perubahan perilaku siswa dimana mereka dapat memahami, mengerti, dan menguasai keterampilan bahasa Arab yang meliputi menulis, membaca, mendengarkan, berbicara dengan baik dan benar". ${ }^{2}$

Dalam sebuah ungkapan : الطريقـة أهـم مـن الهـادة artinya Metode lebih penting dari subtansi; Pada hakekatnya metode lebih penting daripada materi (subtansi), statemen ini menarik untuk dicerna dan dianalisis, karena ia akan memberi implikasi yang jelas pada paradigm metode pembelajaran kita pada khususnya metode pembelajaran bahasa Arab. Kenyataan ini menunjukkan bahwa seorang yang cukup pintar dan menguasai suatu ilmu tertentu ternyata acap kali menemui semacam batu sandungan dalam mengkomunikasikan ilmu tersebut secara efektif. ${ }^{3}$

Metode titik tolaknya terletak pada cara atau jalan yang akan ditempuh dalam penyajian pelajaran atau materi pelajaran tertentu sehingga mudah diterima dan diserap oleh anak didik. Sebagai suatu ilmu yang membicarakan bagaimana cara menyampaikan atau menyajikan bahan pelajaran sehingga dapat diterima, dipahami dan dikuasai oleh anak didik. Mempelajari metode saja belumlah menjamin seorang guru akan berhasil dengan baik dalam tugasnya. Karena

Chotibul Umam, Aspek-Aspek Fundamental Dalam Mempelajari Bahasa Arab, 1 .(Bandung: PT Al-Ma'arif),hlm: 9

2Ali Ridho, al-Marji' fi al-Lughah al-Arabiyah fi Nahwiha wa Sharfiha; (Juz I; Beirut; Darul2

.Fiqri, ttt), h. 7

Azhar Arsyad, Metode Pembelajaran Bahasa Asing (Cet. I; Ujung Pandang: Yayasan 3 Ahkam, 1419 H/1998 M), h. 1 
metode adalah baru satu komponen atau satu faktor saja dalam pendidikan, dimana faktor tujuan, faktor situasi murid dan kepribadian guru juga dapat mempengaruhi berhasil tidaknya pengajaran. Mempelajari metode pengajaran jelas merupakan suatu keharusan mutlak bagi seorang guru, dimana guru harus memiliki pengetahuan dan penguasaan materi/teori yang matang ${ }^{4}$.

Dalam menggunakan metode yang tepat, diharapkan setidak-tidaknya dapat menghasilkan efektifitas pengajaran, dimana guru dituntut untuk berkreatifitas melakukan apa saja yang membuat siswa belajar, yang dalam hal ini guru tidak perlu menggunakan intimidasi, menakut-nakuti, penggunaan hukuman fisik, atau bentuk hukuman lainnya yang biasanya tidak disukai oleh siswa atau kebanyakan orang.

Dengan metode pembelajaran yang digunakan dapatlah memudahkan siswa belajar sesuatu yang berguna dan bermanfaat, bagaimana memadukan antara isi dan nilai yang terkandung dalam pembelajaran, dan belajar diharapkan dapat membentu siswa untuk meningkatkan kemampuan yang sesuai dengan tujuan instruksional yang ingin dicapai. Berdasarkan uraian diatas, maka penulis menarik rumusan masalah sebagai berikut :

1. Bagaimana Urgensi Metode Pembelajaran Bahasa Arab?

2. Bagaimana Ragam Metode Pembelajaran Bahasa Arab?

\section{PEMBAHASAN}

\section{A. Urgensi Metode Pembelajaran Bahasa Arab}

Dalam bahasa Arab kata metode berasal dari kata taraqa, yatruqu. (طرق بطرق مصدره طريقة) yang berarti jalan, cara, yang sinonim dengan kata uṣūb yang berarti jalan, cara, metode dan system. ${ }^{5}$

4 Tayar Yusuf dan Syaiful Anwar, Metodologi Pengajaran Agama Dan Bahasa Arab, (Jakarta: Raja Grafindo Persada, 1995), h.2.

A.W Munawir, Kamus al-Munawir Arab Indonesia Terlengkap (Yogyakarta: al-5 Munawir, 1984), h. 1395 
Dalam bahasa Arab Approach disebut al-Madkhal, adalah seperangkat asumsi mengenai hakekat belajar mengajar bahasa, sifatnya aksiomatik (filosofis). Metode adalah rencana menyeluruh yang berkenaan dengan penyajian materi bahasa secara teratur, tidak ada satu bagian yang bertentangan dengan yang lain dan semuanya berdasarkan approach yang telah dipilih, sifatnya procedural. Sedangkan Teknik (Ușlūb) yaitu apa yang sesungguhnya terjadi di dalam kelas dan merupakan pelaksanaan dari metode, sifatnya implementatif. ${ }^{6}$

Sebagai salah satu komponen pembelajaran, metode mempunyai peran yang sangat penting dalam kegiatan belajar mengajar. Bahkan dapat dikatakan bahwa dalam kegiatan belajar mengajar semuanya menggunakan metode. Karena metode merupakan suatu alat untuk menyajikan bahan atau materi pelajaran dalam rangka untuk mencapai tujuan pengajaran yang akan disampaikan kepada peserta didik $^{7}$. Sedangkan menurut Zakiyah Daradjat metode adalah suatu cara kerja yang sistematis dan umum, seperti cara kerja ilmu pengetahuan ${ }^{8}$.

Sedangkan pembelajaran sendiri merupakan suatu upaya yang disengaja dan direncanakan sedemikian rupa oleh pihak guru, sehingga memungkinkan terciptanya suasana dan aktivitas belajar yang kondusif bagi para siswanya.

Proses pembelajaran adalah dua rangkaian kegiatan yang dilakukan oleh seorang pendidik yang hal ini disebut mengajar disusul oleh kegiatan yang disebut belajar yang berlangsung pada waktu yang telah ditentukan guna mencapai tujuan tertentu.

Dari uraian tersebut diatas maka dapat disimpulkan bahwa metode pembelajaran merupakan cara yang sistematis dalam menyampaikan materi

Azhar Arsyad, Bahasa Arab dan Metode Pembelajaranny, beberapa pokok-pokok 6 pokiran, (Fakultas Tarbiyah IAIN Alauddin Makassar, Ujung Pandang, 1997), h. 19

.Abdul Hamid, dkk. Pembelajaran Bahasa Arab, (UIN Malang Press, 2008), h.3 7

8 Zakiyah Daradjat, Metodik Khusus Pengajaran Agama Islam,(Jakarta :Bumi Aksara, 1995), h. 1. 
kepada siswa guna mencapai tujuan yang diinginkan, dengan melihat definisi tersebut diatas, maka tujuan metode pembelajaran adalah :

a. Memberi jalan untuk mencapai suatu tujuan pembelajaran yang ditempuh oleh guru dan siswa.

b. Memberi gambaran rencana secara meyeluruh dalam pencapaian tujuan pembelajaran secara sistematis

c. Memudahkan pencapaian tujuan pembelajaran

Melihat dari definisi dan tujuan metode pembelajaran diatas, maka dapat disimpulkan pula metode ialah cara atau jalan yang ditempuh oleh guru untuk meyampaikan materi pelajaran kepada siswa. Karena itu setelah guru memikirkan bahan pelajaran, maka hendaklah ia memikirkan cara penyampaian bahan tersebut dalam pikiran siswa. Guru harus memikirkan metode yang paling baik untuk menyusun bahan itu, dan menjadikan susunanan bahan mata pelajaran itu sebagai mata rantai sambung menyambung". Ibnu khaldun berkata, "Sesungguhnya pembelajaran itu merupakan profesi yang membutuhkan pengetahuan, keterampilan, dan kecermatan karena ia sama halnya dengan pelatihan kecakapan yang memerlukan kiat, strategi dan ketelatenan, sehingga menjadi cakap dan professional." Penerapan metode pembelajaran tidak akan berjalan dengan efektif dan efisien sebagai media pengantar materi pembelajaran bila penerapannya tanpa didasari dengan pengetahuan yang memadai tentang metode itu. Sehingga metode bisa saja akan menjadi penghambat jalannya proses Pembelajaran, bukan komponen yang menunjang pencapaian tujuan, jika tidak tepat aplikasinya. Oleh karena itu, penting sekali untuk memahami dengan baik dan benar tentang karakteristik suatu metode.

Belajar adalah suatu proses usaha yang dilakukan oleh seseorang untuk memperoleh suatu perubahan tingkah laku yang baru secara keseluruhan sebagai hasil pengalamannya sendiri dengan lingkungannya ${ }^{10}$

Abu Bakar Muhamad, Metode Khusus Pengajaran Bahasa Arab, (Surabaya: Usaha Nasional. 9 .1981), h. 8 
Mengajar pada hakikatnya adalah suatu proses, yakni proses mengatur, mengorganisasi lingkungan yang ada disekitar siswa sehingga dapat menumbuhkan dan mendorong siswa melakukan proses belajar mengajar. Pada tahap berikutnya mengajar adalah proses memberikan bimbingan atau bantuan kepada siswa dalam proses belajar mengajar ${ }^{11}$.

Dalam buku Crucial issues in education karangan Ehlers dan Lee mengatakan bahwa: Good theaching will have to aspect. It will include the communication of positive knowledge and accepted principles a long with an analysis of the line of reasoning, or wherever appropriate, the repetition, or at least the description of the experiments by wich the conclusions were reached. The other aspect discussion of diverse view on issues stiil unstelled. "Mengajar yang baik meliputi dua aspek, yaitu terciptanya komunikasi atau memberikan suatu ilmu pengetahuan yang positif dan diterimanya sebuah analisis sebagai dasar pemikiran atau merupakan sedikit gambaran dari suatu percobaan (penelitian) yang mana kesimpulannya dapat dijangkau. Aspek yang lain adalah mendiskusikan macam-macam pendapat atau pendengaran dalam suatu hal yang belum pasti kebenarannya". ${ }^{12}$

Kegiatan belajar mengajar adalah suatu kondisi yang sengaja diciptakan, gurulah yang menciptakannya guna membelajarkan siswa. Guru yang mengajar dan siswa belajar. Dalam kegiatan belajar mengajar, guru dan siswa terlibat dalam interaksi dengan bahan pelajaran sebagai medianya. Kegiatan belajar mengajar adalah proses yang bertujuan. Tujuannya tersebut dinyatakan dalam rumusan tingkah laku yang diharapkan dimiliki siswa setelah menyelesaikan pengalaman belajarnya (Saryatna Rafi'i, 1985:52).

.Nana Sudjana, Dasar-dasar Proses Belajar Mengajar, (Bandung : Sinar Baru,1989), h. 2911 
Perlu diketahui bahwa proses belajar yang bermakna adalah proses belajar yang melibatkan berbagai aktivitas siswa. Untuk itu guru harus berupaya untuk mengaktifkan siswa.

\section{B. Ragam Metode Pembelajaran Bahasa Arab}

Dalam dunia pendidikan, proses belajar mengajar merupakan proses belajar yang kompleks sifatnya. Hal ini disebabkan banyaknya unsur yang berpengaruh dalam kegiatan tersebut. Disamping faktor siswa, guru merupakan faktor yang berpengaruh dalam proses belajar mengajar, demikian juga dengan tujuan dan kondisi atau situasi yang terlibat langsung dalam terjadinya proses belajar mengajar. Seorang guru harus memiliki pandangan yang luas mengenai substansi yang berhubungan dengan pengajarannya, guru memiliki peran yang sangat penting dalam menentukan kualitas dan kuantitas pengajaran yang dilaksanakan. Oleh karena itu guru harus memikirkan dan membuat perencanaan secara seksama karena persiapan merupakan cermin, yang dengannya dapat melihat sejauh mana kemampuan guru, kepintaranya memilih bahan pelajaran dan kemahirannya mendidik serta meningkatkan kesempatan belajar bagi siswanya, dan memperbaiki kualitas mengajar. Untuk memenuhi hal tersebut guru dituntut mampu mengelola proses belajar mengajar yang membrikan rangsangan kepada siswa, sehingga ia mau belajar. Disamping itu guru juga harus tepat memilih bahan pengajaran.

Untuk mempertinggi suatu metode tertentu, penerapan suatu metode kedalam setiap situasi pengajaran haruslah mempertimbangkan dan memperhatikan berbagai kemungkinan-kemungkinan, kalau tidak mau maka bukan saja berakibat proses belajar pengajaran menjadi terhambat, tetapi dapat juga berakibat lebih jauh, yaitu tidak tercapainya tujuan pengajaran sebagaimana yang telah diterapkan.

Adapun hal-hal yang harus diperhatikan dalam metode pengajaran adalah sebagai berikut :

1. Tujuan yang hendak dicapai 
2. Kemampuan guru

3. Anak didik

4. Situasi dan kondisi pengajaran

5. Fasilitas yang tersedia

6. Waktu yang tersedia

7. Kebaikan dan kekurangan suatu metode. ${ }^{13}$

Untuk lebih jelasnya akan penulis jelaskan faktor-faktor tersebut diatas sebagai berikut :

\section{a. Tujuan Yang Hendak Dicapai}

Dalam pemilihan metode, guru hendaklah mampu melihat tujuan yang hendak dicapai dalam pembelajaran, dan membawa anak didik ke dalam situasi pemilihan metode yang dianggap paling cocok atau tepat dan serasi untuk diterapkan. Dengan demikian, maka tujuan yang ingin dicapai dari masing-masing mata pelajaran itu haruslah menjadi perhatian utama bagi seorang guru dalam menetapkan metode apa yang akan dipakai dalam mengajar.

\section{b. Kemampuan Guru}

Efektif tidaknya suatu metode juga sangat dipengaruhi pada kemampuan guru memahami metode tersebut, disamping kepribadian guru memang cukup dominan pengaruhnya. Dengan demikian faktor penguasaan metode seorang guru juga hal yang perlu diperhatikan.

\section{c. Anak Didik}

Guru dihadapan dengan siswa yang memiliki potensi dan fitrah yang memberi kemungkinan dan sekaligus harapan untuk berkembang dengan baik kearah pribadi yang sempurna. Fitrah setiap individu anak didik, telah diberikan oleh Allah swt, berupa keimanan dan tauhid. Akan tetapi iman dan tauhid itu dapat saja berubah kearah kekufuran manakala tidak disiram dan dipupuk dengan pendidikan dan bimbingan kejalan yang menuju kearah keimanan dan islam.

Hal ini sejalan dengan sabda Rasulullāh saw yang diriwayatkan Bukhārī dan Muslim yang berbunyi : 


\section{مأما من موحلود إلا يُولد على اللفطرة، وإنما أ بِواه يهودانه أوينصر انهه أويمجسانه إلهود ( رواه البنخارى ومسلمسلم )}

"Tiadalah manusia itu lahir kecuali dalam keadaan fitrah, maka kedua orang tuanyalah yang menjadikan dia yahudi, nasrani atau majusi. (H.R. Bukharī-Muslim)

\section{d. Situasi dan kondisi pengajaran dimana berlangsung}

Situasi dan kondisi saat berlangsungnya pengajran hendaknya diperhatikan dan dipertimbangkan didalam pemilihan metode pengajaran, baik kondisi fisik gedung, keadaan guru dan siswa didalam kelas, adakah ia dekat kebisingan, ataukah mungkin dalam keadaan lelah sehabis olah raga. Untuk itu perlu dipilihkan metode yang dianggap tepat, jika pengajaran ingin berhasil secara optimal.

\section{e. Fasilitas Yang Tersedia}

Tersedianya sarana dan prasarana atau media pengajaran, misalnya gedung sekolah, buku-buku bacaan, alat latihan praktikum, alat peraga serta fasilitasfasilitas lainnya sangat menentukan terhadap efektif tidaknya suatu metode. Sehingga seyogyanya seorang guru yang baik, harus menyiapkan alat peraga atau media pengajaran pada setiap kali akan mengajar.

\section{f. Waktu Yang Tersedia}

Dalam menggunakan metode tertentu, hal yang juga harus diperhatikan adalah waktu. Sebab dalam menyampaikan materi pelajaran, metode harus disesuaikan agar tepat waktu untuk materi pelajaran yang lain, biasanya waktu pelajaran telah ditentukan atau ditetapkan oleh silabus/ kurikulum. Kemudian guru mempertimbangkan waktu pengajaran yang telah disediakan tersebut dengan pemilihan metode pengajaran yang pas.

\section{g. Kebaikan Dan Kekurangan Suatu Metode}

Sudah barang tentu suatu metode memiliki kelebihan dan kekurangan . akan tetapi kekurangan suatu metode tertentu dapat dilengkapi oleh keunggulan atau kelebihan dalam suatu metode yang lain. Dengan memperhatikan dan 
mempertimbangkan hal-hal tersebut diatas, diharapkan seorang guru dapat memilih metode yang tepat atau dapat memadukan kelebihan0kelebihan dari masing-masing metode, sehingga dapat mencapai tujuan pengajaran.

Sebelum membicarakan pengertian metode pembelajaran, terlebih dahulu penulis akan menjelaskan bahwa bahasa Arab merupakan mata kuliah yang mengembangkan keterampilan berkomunikasi lisan dan tulisan untuk memahami dan mengungkapkan informasi, pikiran, persaaan serta mengembangkan ilmu pengetahuan, teknologi dan budaya. Area utama dari pembelajaran bahasa Arab meliputi: empat aspek, yaitu Menyimak, berbicara, membaca dan menulis. Ke empat aspek tersebut saling berhubungan, misalnya, ketrampilan mendengarkan memberikan kontribusi terhadap perkembangan berbicara, kedua kemampuan tersebut diperkuat oleh kemampuan membaca, semantara keterampilan menulis memberikan kontribusi pada ketrampilan membaca dalam bentuk teks atau dokumentasi.

Secara sederhana, metode Pembelajaran bahasa Arab dapat digolongkan menjadi dua macam, yaitu: pertama, metode tradisional/klasikal dan kedua, metode modern.

Metode Pembelajaran bahasa Arab tradisional adalah metode Pembelajaran bahasa Arab yang terfokus pada "bahasa sebagai budaya ilmu" sehingga belajar bahasa Arab berarti belajar secara mendalam tentang seluk-beluk ilmu bahasa Arab, baik aspek gramatika/sintaksis (Qawā'id al-Nahwu), morfem/morfologi (Qawā'id al-Șarf) ataupun sastra (adāb). Metode yang berkembang dan masyhūr digunakan untuk tujuan tersebut adalah Metode qawā'id dan tarjamah. Metode tersebut mampu bertahan beberapa abad, bahkan sampai sekarang pesantren-pesantren di Indonesia, khususnya pesantren salafiah masih menerapkan metode tersebut. Hal ini didasarkan pada hal-hal sebagai berikut: Pertama, tujuan Pembelajaran bahasa arab tampaknya pada aspek budaya/ilmu, terutama naḥwu dan ilmu șarf. Kedua kemampuan ilmu nahwwu dianggap sebagai syarat mutlak sebagai alat untuk memahami teks/kata bahasa Arab klasik yang tidak memakai harakat, dan tanda baca lainnya. Ketiga, bidang 
tersebut merupakan tradisi turun temurun, sehingga kemampuan di bidang itu memberikan "rasa percaya diri (gengsi) tersendiri di kalangan mereka".

Metode Pembelajaran bahasa Arab modern adalah metode Pembelajaran yang berorientasi pada tujuan bahasa sebagai alat. Artinya, bahasa Arab dipandang sebagai alat komunikasi dalam kehidupan modern, sehingga inti belajar bahasa Arab adalah kemampuan untuk menggunakan bahasa tersebut secara aktif dan mampu memahami ucapan/ungkapan dalam bahasa Arab. Metode yang lazim digunakan dalam Pembelajarannya adalah metode langsung (tarīqah al- mubāsyarah). Munculnya metode ini didasari pada asumsi bahwa bahasa adalah sesuatu yang hidup, oleh karena itu harus dikomunikasikan dan dilatih terus sebagaimana anak kecil belajar bahasa.

Agar siswa dapat menguasai bahasa arab dengan baik, seorang guru perlu menguasai bermacam-macam metode pengajaran bahasa arab. Kita mengenal banyak sekali macam metode pengajaran, dari sekian banyak metode yang dipakai atau ditetapkan dalam pengajaran, biasanya seorang guru dalam menetapkan metode tersebut memperhatikan minat siswa agar dapat tercurah pada pelajaran. Diantara metode pembelajaran bahasa Arab adalah ${ }^{14}$ :

\section{a. Metode Qawaid (tata bahasa) dan Terjemah}

Metode ini sulit ditentukan secara pasti sejarah lahirnya ini. Hal ini disebabkan metode ini ada di sebagian besar negara-negara di dunia ini. Akan tetapi juga sulit menghubungkan metode ini dengan salah satu ilmuwan, akan tetapi dikenal bahwa metode ini berhubungan dengan pengajaran bahasa Latin dan Yunani, kedua bahasa tersebut telah tersebar di beberapa bidang pengajaran sepanjang abad pertengahan di Eropa. Seorang ilmuwan bernama Plotz mengadopsi beberapa tekniknya uslubnya pada akhir abad ke-19. Dia melakukan hal itu sampai uṣlūb teknik-tekniknya itu berpindah kepada dua negara lain di dunia. Barangkali metode ini merupakan metode terbanyak yang tersebar di negara Indonesia dan lebih khusus di pondok-pondok pesantren.

14 Mulyanto Sumardi, Pengajaran Bahasa Asing (Sebuah Tinjauan Dari Segi Metodologis) (Jakarta: Bulan Bintang, 1974), h.32. 
Para pakar dan praktisi pembelajaran bahasa asing sering juga menyebut metode ini dengan metode tradisional. Penyebutan tersebut berkaitan dengan sebuah cerminan terhadap cara-cara dalam jaman Yunani Kuno dan Latin dalam mengajarkan bahasa. Asumsi dasar metode ini adalah adanya 'logika semesta' (universal logic) yang merupakan dasar semua bahasa di dunia, sedangkan tata bahasa adalah cabang logika.

Metode ini ditujukan kepada peserta didik agar, (1) lebih mempu membaca naskah berbahasa Arab atau karya sastra Arab, dan (2) memiliki nilai displin dan perkembangan intelektual. Pembelajaran dalam metode ini didominasi dengan kegiatan membaca dan menulis. Adapun kosakata yang dipelajari adalah kosakata dari tes bacaan, di mana kalimat diasumsikan sebagai unit yang terkecil dalam bahasa, ketepatan terjemahan diutamakan, dan bahasa Ibu digunakan dalam proses pembelajaran.

Metode tata bahasa dan terjemah ini mengarah pada:

1. Menghasilkan siswa yang terdidik, terlatih akan pengetahuan kebudayaan sastra yang tinggi, dan mempunyai daya apresiasi sastra;

2. Menghasilkan siswa yang hapal akan materi-materi nahwu dan teks-teks sastra;

3. Menghasilkan siswa yang berkompeten untuk menerjemahkan secara bebas dari bahasa induk kepada bahasa sasaran.

Untuk merealisasikan tujuan ini, metode tata bahasa dan terjemah menggunakan teknik sebagai berikut :

1. Otak siswa dipenuhi dengan kaidah-kaidah nahwwu dan daftar tașrïf serta wazan-wazannya;

2. Menjadikan siswa hapal akan daftar-daftar vocabulary dan sinonimnya di luar kepala;

3. Mengajari siswa membaca secara detail/terinci dan analisis;

4. Mengajari siswa menulis topik-topik karangan dengan mengambil cuplikan kalimat-kalimat, alinea-alinea dari sastrawan dan penyair;

5. Melatih siswa menerjemahkan teks sastra yang tinggi.

Prosesnya di dalam kelas yaitu : 
1. Guru menerjemahkan kosa kata yang baru, kemudian menugaskan siswa untuk menghapal vocabulary itu dan meminta untuk diperdengarkan kembali pada hari berikutnya;

2. Guru meminta sebagian siswa untuk membaca teks dan mengoreksinya. Kemudian guru membaca teks tersebut kalimat per kalimat, kemudian meminta salah seorang siswa yang pandai untuk menerjemahkan kalimat itu atau guru itu sendiri yang menerjemahkannya;

3. Guru mengeluarkan kaidah-kaidah nahwu dari teks tersebut kemudian menjelaskannya dengan penjelasan yang terperinci, begitu juga terkadang bisa meminta siswa untuk menyusun kalimat yang sesuai dengan kaidah tersebut, dan selanjutnya siswa memulai untuk menjawab latihan soalsoal;

4. Guru memberi tugas kepada siswa untuk menghapalkan tata bahasa di luar kepala dan memperdengarkannya pada kesempatan/jam pelajaran yang akan datang;

5. Terkadang siswa menerjemahkan teks dengan terjemahan bebas

Evaluasi dari metode ini :

1. Sesungguhnya sasaran metode ini terbatas dan sulit ditangani/ diperoleh;

2. Metode ini memusatkan perhatian pada keterampilan membaca dan menulis, mengabaikan keterampilan menyimak dan berbicara;

3. Metode ini tidak dapat merealisasikan tujuannya dalam membiasakan siswa untuk menulis dengan benar;

4. Metode ini hanya sesuai bagi siswa yang cerdas saja;

5. Metode ini mengharuskan siswa berpikir dengan bahasa ibu, kemudian pemikiran itu diterjemahkan ke dalam otaknya yakni kepada bahasa sasaran;

6. Metode ini terjadi secara tidak sadar, hal itu menghambat cepatnya pengajaran bahasa;

7. Metode ini menjadikan/membuat guru jadi malas;

8. Peran guru di dalam metode ini gampang, jika dia menguasai bahasa asing.

\section{b. Metode Langsung (Mubāsyarah)}

Karena adanya ketidak puasan dengan metode qawā'id dan tarjamah, maka terjadi suatu gerakan penolakan terhadap metode tersebut menjelang pertengahan abad ke 19. Banyak orang Eropa yang merasa bahwa buku-buku pembelajaran 
bahasa asing yang beredar tidaklah praktis, karena tidak mengajarkan bagaimana berbahasa namun lebih memperhatikan pembicaraan tentang bahasa. Karena itu, banyak kemudian bergulir ide-ide untuk meperbaharui metode tersebut.

Berdasarkan asumsi yang ada dalam proses berbahasa antara Ibu dan anak, maka F.Gouin (1980-1992) mengembangkan suatu metode yang diberi nama dengan metode langsung (țaīqah mubāsyarah), sebuah metode yang sebenarnya juga pernah digunakan dalam dunia pembelajaran bahasa asing sejak jaman Romawi ( \pm abad XV). Metode ini memiliki tujuan yang terfokus pada peserta didik agar dapat memiliki kompetensi berbicara yang baik. Karena itu, kegiatan belajar mengajar bahasa Arab dilaksanakan dalam bahasa Arab langsung baik melalui peragaan dan gerakan. Penerjemahan secara langsung dengan bahasa peserta didik dihindari.

Metode ini disebut metode langsung karena selama pelajaran guru berlangsung menggunakan bahasa asing yang diajarkan, sedang bahasa murid tidak digunakan. Jadi dengan metode ini, guru dalam mengajar langsung menggunakan bahasa asing melalui percakapan, diskusi dan membaca bahan yang dipelajari. Sedangkan untuk menjelaskan suatu arti kata atau kalimat digunakan alat peraga.

Sasarannya metode ini mengarah pada :

1. Menjadikan siswa mampu berpikir dengan bahasa sasaran dalam percakapan, membaca dan menulis;

2. Menggunakan bahasa baru secara langsung tanpa terjemahan dengan tujuan sebagai komunikasi dan interaksi;

Prosedurnya, Guru menggunakan pengantar secara lisan tanpa guru harus membaca dan menulis. Program pengajaran bahasa ini dimulai dengan mengajarkan kata-kata ungkapan-ungkapan yang menunjukkan pada sesuatu dan perbuatan-perbuatan yang dapat diindera atau dapat diperagakan dan selanjutnya belajar beralih pada situasi-situasi bahasa yang berproses pada dialog dan yang diucapkannya itu adalah ucapan sehari-hari, memanfaatkan gambar-gambar tanpa tergantung pada terjemahan. Dalam membaca, guru memulai terlebih dahulu 
membaca teks, kemudian setelah itu menyuruh siswa untuk membaca. Adapun menulis, maka merupakan penyempurnaan belajar dengan cara mengisi yang kosong (titik-titik) dan menyusun kalimat-kalimat yang sederhana. Keistimewaan metode ini adalah efektif dalam hasilnya, disamping itu mudah dan elastis/fleksibel, dan mempunyai sentuhan manusiawi. Metode ini berpusat pada kemampuan komunikasi dan memberikan kesempatan kepada siswa untuk berpartisipasi. Akan tetapi kekurangannya adalah sebagai berikut :

1. Metode ini tidak cocok untuk tingkatan lanjutan yang sudah maju;

2. Metode ini melalaikan kemampuan menulis.

\section{c. Metode Silent Way (Guru Diam)}

Metode ini digulirkan oleh C. Gatteno (1972). Kendati ia mengembangkan teori dan metode pembelajaran yang terpisah dengan teori Chomsky, namun didalamnya banyak persamaan. Ide dasarnya adalah bahwa belajar sangat bergantung pada diri (self) seseorang. Diri tersebut mulai berfungsi pada waktu manusia diciptakan dalam kandungan, dimana sumber awal tenaganya dalah DNA (deoxyribonu acid). Diri menerima masukan-masukan dari luar dan mengolahnya sehingga menjadi bagian dari diri itu sendiri.

Dalam penggunaan metode silent way, guru lebih banyak diam, ia menggunakan gerakan, gambar dan rancangan untuk memancing dan membentuk reaksi. Guru menciptakan situasi dan lingungan yang mendorong peserta didik "mencoba-coba" dan menfasilitasi pembelajaran. Seolah hanya sebagai pengamat, guru memberikan model yang sangat minimal dan membiarkan peserta didik berkembang bebas, mandiri dan bertanggung jawab. Adapun penjelasan, koreksi dan pemberian model sangat minim, lalu peserta didik membuat generalisasi, simpulan dan aturan yang diperlukan sendiri. Hanya saja, di dalamnya masih digunakan pendekatan struktural dan leksikal dalam pembelajaran.

\section{d. Community Language Learning (Belajara Bahasa Berkelompok)}

Metode yang dikatakan merepresentasikan pendekatan Humanis ini diperkenalkan oleh C.A. Curren dan rekan-rekannya (1976). Istilah humanistis yang dimaksudkan adalah sebagai percampuran semua emosi atau perasaan 
seseorang dalam kegiatan belajar mengajar. Teori ini didasarkan pada asumsi bahwa apa yang dipelajari manusia itu bersifat afektif, disamping kognitif. Jadi, peserta didik belajar bahasa adalah mengalami semua input atau masukan dari luar secara menyeluruh melalui perasaan, di samping pikiran.

Metode ini mempunyai tujuan yaitu penguasaan bahasa sasaran oleh peserta didik yang mendekati penutur aslinya. Mereka belajar dalam suatu komunitas atau berkelompok (teman belajar dan gurunya), melalui interaksi dengan sesama anggota komunitas tersebut. Pembelajaran dirancang sesuai dengan tahapan perkembangan manusia dalam mempelajari bahasa, yakni (1) tahap tergantung sepenuhnya (bayi), (2) tahap sedikit lepas dari ketergantungan, (3) tahap keberadaan dalam situasi yang terpisah, (4) tahap dewasa, dan (5) tahap kebebasan. Peran guru di sini adalah menciptakan situasi dalam 5 tahapan tersebut.

\section{e. Total Physical Respon}

Metode ini dicetuskan oleh James J. Asher, seorang ahli psikologi dari Amerika. Metode ini berpijak pada pembelajaran bahasa melalui aktivitas psikomotorik. Pelajaran disampaikan pada tahap awal secara inplisit, sementara setelah pada tahap lanjutan diberkan secara eksplisit. Dalam suasana belajar implisit, tidak dilakukan pembetulan kesalahan dan penghafalan kaidah-kaidah, sedangkan pada pembelajaran secara eksplisit merupakan kebalikannya.

Metode 'respon psikomotorik total' bertujuan agar peserta didik memiliki kemampuan lisan pada tahap awal pembelajaran. Jadi tujuan akhirnya adalah keterampilan berbicara dasar. Pembelajaran dengan cara menggabungkan kegiatan ber-bahasa dan gerakan merupakan ciri dasar dalam pembelajaran bahasa Arab. Sehingga, proses pembelajaran seperti proses pemerolehan bahasa pada anak: bahasa yang didengar oleh anak banyak berisi perintah yang kemudian direspon dengan tindakan fisik. Di sini, guru berperan aktif mengarahkan kegiatan pembelajaran; menentukan isi kegiatan menjadi model, dan memilih bahan-bahan pelajaran pendukung.

\section{f. Metode Mim-Mem (Mimicry-Memorization Method)}


Istilah mim-mem bearasal dari singkatan mimicray (meniru) dan memorizattion (menghapal), yaitu sebuah proses mengingat sesuatu dengan menggunakan kekuatan memori. Metode yang juga sering disebut informant-drill method dalam penggunaannya sering menekankan latihan-latihan baik dilakukan oleh selain pengajar, juga oleh seorang informan penutur asli (native informant). Kegiatan belajar berupa demontrasi dan latihan (drill) gramatika dan struktur kalimat, teknik pengucapan, dan penggunaan kosakata dengan mengikuti atau menirukan guru dan informan penutur asli. Pada saat melakukan drilling, native informant bertindak sebagai seorang drill master. Ia mengucapkan beberapakalimat sampai akhirnya peserta didik menjadi hapal. Gramatika diajarkan secara tidak langsung melalui model-model kalimat. Jadi metode ini didunakan oleh guru dengan jelas membacakan teks bahasa arab (materi pelajaran) dan kemudian ditirukan oleh siswa beberapa kali untuk dihafal atau menurut metode ini metode menghafal berupa demonstrasi dan drill menggunakan kosa kata dengan menirukan guru selaku drill master.

\section{g. Metode Audiolingual (Sam ’iyyah Syafahiyyah)}

Metode ini lebih populer diterapkan karena sebab kepentingan perang. Dalam sejarah Perang Dunia II, Amerika memerlukan personil tentara yang mahir berbahasa asing untuk kepentingan ekspansinya. Oleh karena itu, metode ini dikenal juga dengan army method. Bahasa yang dipelajari lebih dicurahkan pada perhatian dalam pelafalan kata, tubian (drills) berkali-kali secara intensif. Mirip dengan metode sebelumnya, tubian (drill) inilah yang menjadi tehnik dasar dalam pembelajaran. Hanya saja konsentrasi tujuan lebih pada penguasaan keterampilan mendengar dan berbicara.

Metode ini bertujuan untuk menghasilkan siswa yang menguasai dengan baik keterampilan berbahasa yang empat macam, yaitu berupa (1) listening/menyimak, (2)/speacking/berbicara, (3) reading/membaca, dan (4)writing/menulis, dengan memperhatikan pada aspek ucapan, bahwa bahasa Arab pada dasarnya merupakan sarana komunikasi di antara manusia dan bangsa. 
Untuk merealisasikan tujuan ini hendaklah mengikuti asumsi-asumsi sebagai berikut:

1. Bahasa pada dasarnya merupakan tuturan utama, oleh karena itu perhatian harus ditujukan pada penuturan bukan pada membaca dan menulis.

2. Urutan pengajaran bahasa Arab adalah : (1). Menyimak; (2). Menuturkan; (3). Membaca; (4). Menulis.

3. Dimungkinkan belajar bahasa Asing dengan metode yang digunakan oleh anak kecil dalam berbahasa ibu.

4. Bahasa adalah kebiasaan, dan kebiasaan diperoleh dengan latihan, oleh karena itu bahasa dapat diperoleh dengan latihan.

5. Kita harus mempelajari bahasa itu sendiri, kemudian berlatih dengan bahasa itu dan benar-benar kita latihkan, bukan tidak perlu memahami aturanaturannya, tata bahasanya, ataupun perubahan-perubahannya.

Prosedur Metode ini adalah :

1. Tahapan lisan yang murni, yang bertujuan untuk melatih pendengaran dan ucapan/mulut di mana guru melakukan proses percakapan yang /inderawi dari kehidupan sehari-hari yang berdasarkan kepada gambar-gambar dan peragaan selama 2-3 minggu.

2. Tahap permulaan membaca -murid-murid mulai membaca percakapan/ teks-teks yang pernah mereka dengar dan mereka latihkan bahkan mereka terkadang menghapalkannya. Tulisan masuk secara bertahap ke dalam fase membaca. Langkah pengajarannya menjadi sebagai berikut:

a. Mendengar dengan keadaan buku tertutup;

b. Mendengar dengan mengulang, dengan keadaan tertutup.

b. Mendengar dengan keadaan buku dibuka (menghubungkan bunyi bunyi dengan lambang tulisan).

a. Membaca bersama-sama dengan keadaan buku terbuka.

b. Membaca berkelompok dengan keadaan buku terbuka.

c. Membaca individual dengan keadaan buku terbuka.

d. Menjawab pertanyaan-pertanyaan untuk mengoreksi/pemahaman;

e. Latihan pola-pola kalimat.

Metode ini memiliki beberapa kelebihan diantaranya : 
1. Metode ini memandang bahasa dengan pandangan yang/universal dan dengan metode yang /integral, metode ini mementingkan pada semua kemampuan (menyimak, menuturkan, membaca dan menulis).

2. Menjadikan siswa lebih /partisipasipatif dan /potensial/aktif di dalam ruang belajar, metode ini menghilangkan /dua fenomena rasa malu dan takut.

3. Variasi tehnik-tehnik dan latihan-latihannya menghilangkan rasa /kebosann/jenuh yang ada pada siswa.

4. Sesungguhnya metode ini pertama sekali memperhatikan bahasa yang hidup dan nyata dalam kehidupan sehari-hari, kemudian berpindah kepada bahasabahasa kebudayaan.

Metode ini mempunyai beberapa kelemahan dan kekurangan, di antaranya:

1. Dari satu segi metode ini banyak pengulangan yang terkadang mengakibatkan kejenuhan dan dari segi yang lain meniru persis dengan apa yang ditiru (seperti burung Beo).

2. Lebih memusatkan pada segi lisan daripada yang lainnya.

3. Terkadang metode ini tidak cocok digunakan oleh yang sudah berusia tua, metode ini hanya sesuai dengan anak-anak saja.

\section{h. Pendekatan Komunikatif (madkhal ittiṣālī)}

Ada dua prinsip dasar yang paling penting dalam pendekatan ini, yaitu (1) kebermaknaan (meaning full) dalam setiap bentuk bahasa yang dipelajari. Lalu yang ke(2), bahwa bentuk, ragam dan makna bahasa sangat terkait dengan situasi dan konteks berbahasa. Pendekatan komunikatif tidak terikat pada satu aliran linguistik atau disiplin ilmu tertentu saja, melainkan juga memanfaatkan apa yang menjadi kelebihan dalam aneka ragam aliran atau disiplin ilmu lain. Hal ini sangat berbeda dengan metode Audiolingual yang hanya merujuk pada landasan dasar aliran linguistik struktural dan paham behaviorisme.

Pendekatan ini bertujuan agar peserta didik memiliki kompetensi komunikatif, yaitu kemampuan menggunakan sistem bahasa secara efektif dan benar. Kelancaran menggunakan bahasa yang acceptable menjadi tujuan utama yang ingin di capai. Dalam pembelajaran bahasa Arab dengan pendekatan komunikatif, penguasaan makna (nosi/fikrah) sangat penting, sehingga isi pelajaran disajikan dalam konteks. Sementara struktur bahasa diajarkan 
terintegrasi dalam pengejaran keterampilan berbahasa Arabnya. Kemampuan yang diharapkan tidak hanya keterampilan berbahasa, tetapi juga unsure-unsur kebahasaannya, seperti sharf dan nahwu. Bahan pelajaran berupa dialog, pengalaman peserta didik, latihan ungkapan, namun tubian tidak diberikan hanya bila dianggap perlu. Sedangkan bahasa Ibu dan terjemahan bisa digunakan sekalikali.

\section{i. Metode eklektik (țarīqah al-intiqäiyyah)}

Pendekatan pembelajaran di atas memerlukan metode pembelajaran yang tepat. Plihan yang tepat adalah metode eklektik, yaitu metode gabungan yang mengambil aspek-aspek positifnya baik dari keterampilan maupun pengetahuan bahasa, sehingga mencapai tujuaan dan hasil pembelajaran yang maksimal. Metode eklektif dimaksud mencakup metode percakapan,membaca, latihan, dan tugas.

Dari uraian terdahulu telah dijelaskan tentang kelebihan dan kekurangan dari setiap metode, sebagian para ilmuwan telah berusaha untuk memadukannya, maka muncullah metode Selektif yang tidak mewajibkan guru untuk hanya memahami satu metode saja dan juga jangan memandang bahwa metode tersebut merupakan suatu metode yang paling cocok. Metode selektif berdasar pada hal sebagai berikut ini:

1. Bahwa setiap metode mengajar itu memiliki kebaikan-kebaikan/ kelebihankelebihan yang memungkinkan untuk bisa diambil dari segi manfaatnya/kelebihan-kelebihannya itu;

2. Tidak terdapat satu metode pun yang benar-benar /ideal dan benar-benar salah, akan tetapi setiap metode masing-masing memiliki kelebihan dan kekurangan.

3. Kita harus memandang bahwa setiap metode pengajaran bahasa, antara bagian yang satu dengan yang lainnya saling melengkapi, tidak saling bertentangan satu sama lainnya;

4. Tidak ada satu metode pun yang cocok dengan semua tujuan dan semua siswa;

5. Yang penting dalam setiap pengajaran, hendaklah berkonsentrasi pada (student centre) yang ia butuhkan dan tuntutan situasi-kondisi. 
Yang menjadi dasar penekanan metode ini adalah tergantung kepada kemampuan guru di dalam memilih sesuatu yang cocok dari tehnik-tehnik atau metode-metode pada situasi yang sesuai dengan kebutuhan siswa dengan kondisi belajar-mengajar. Metode ini menuntut terpenuhinya syarat-syarat yang harus dimiliki oleh guru, yaitu sebagai berikut:

1. Guru hendaklah betul-betul memperhatikan/menguasai semua metode dengan memungkinkan mengambil/memanfaatkan berbagai kelebihan dan kekurangan dari metode tersebut;

2. Memilih metode yang cocok yang disesuaikan dengan tingkatan usia para pelajar serta tingkat kebahasaan mereka;

3. Menjaring dengan baik, yaitu dengan memilih metode yang cocok atau yang sesuai dengan buku paket yang digunakan.Para pengikut metode ini hampir memastikan bahwa tidak ada satu pun guru yang dapat mengikuti terusmenerus dalam satu metode yang ditentukan, oleh karena itu maka metode ini menjadi /way out/jalan keluar yang menyenangkan kebiasaaan fanatisme bagi metode pengajaran yang lain.

\section{KESIMPULAN}

Dari penjelasan yang penulis paparkan diatas, dapat simpulkan bahwa metode pembelajaran merupakan cara yang sistematis dalam menyampaikan materi kepada siswa guna mencapai tujuan yang diinginkan, Memberi jalan untuk mencapai suatu tujuan pengajaran yang ditempuh oleh guru dan siswa dalam belajar bahasa arab.

1. Adapun faktor-faktor yang harus diperhatikan dalam metode pengajaran adalah sebagai berikut :
a. Tujuan yang hendak dicapai
b. Kemampuan guru
c. Anak didik
d. Situasi dan kondisi pengajaran
e. Fasilitas yang tersedia
f. Waktu yang tersedia
g. Kebaikan dan kekurangan suatu metode

2. Macam-macam metode pembelajaran dalam bahasa Arab yang dapat digunakan yaitu: 
a. Metode Qawaid (tata bahasa) dan Terjemah

b. Metode Langsung (Mubâsyarah)

c. Metode Silent Way (Guru Diam)

d. Community Language Learning (Belajara Bahasa Berkelompok)

e. Total Physical Respon

f. Metode Mim-Mem (Mimicry-Memorization Method)

g. Metode Audiolingual (Sam'iyyah Syafahiyyah)

h. Pendekatan Komunikatif (madkhal ittishaly)

i. Metode eklektik (tariqah al-intiqaiyyah)

\section{DAFTAR PUSTAKA}

Hamid, Abdul dkk. Pembelajaran Bahasa Arab, UIN Malang Press. 2008

Muhamad, Abu Bakar, Metode Khusus Pengajaran Bahasa Arab, Surabaya: Usaha Nasional. 1981

Arsyad, Azhar Bahasa Arab dan Metode Pembelajaranny, beberapa pokok-pokok pokiran, (Fakultas Tarbiyah IAIN Alauddin Makassar, Ujung Pandang, 1997)

Arsyad, Azhar, Metode Pembelajaran Bahasa Asing (Cet. I; Ujung Pandang: Yayasan Ahkam, 1419 H/1998 M)

Ridho, Ali ttt المرجع فى اللغة العرا بية فى نحوها وصرفها Beirut : Darul Fiqri Juz Awal

Umam, Chatibul, Aspek-Aspek Fundamental Dalam Mempelajari Bahasa Arab, Bandung: PT Al-Ma’arif, 1980

Ehlers and Lee, Crucial issues in education, united states America : Holt Rinehart and Winston. 1963

Sumardi, Mulyanto, Pengajaran Bahasa Asing (Sebuah Tinjauan Dari Segi Metodologis) Jakarta: Bulan Bintang. 1974,

Sudjana, Nana, Dasar-dasar Proses Belajar Mengajar, Bandung : Sinar Baru. 1989

Zaenudin, Radliyah, Metodologi dan Strategi Alternatif Pembelajaran Bahasa Arab, Yogyakarta: Pustaka Rihlah Group, 2005

Slameto, 2003, Belajar dan Faktor-faktor yang mempengaruhinya Jakarta : Rineka Cipta

Suryatna Rafi'I, 1985, Teknik Evaluasi, Bandung : Angkasa 
Tayar Yusuf Dan Syaiful Anwar, 1995, Metodologi Pengajaran Agama Dan Bahasa Arab, Jakarta: Raja Grafindo Persada

Daradjat, Zakiyah Metodik Khusus Pengajaran Agama Islam, Jakarta :Bumi Aksara 